\title{
Reforms and Policies Fostering Georgia as Emerging Market
}

\author{
Nino Paresashvili \\ Faculty of Economics and Business, Ivane Javakhishvili \\ Tbilisi State University \\ cross $^{\text {ref }}$ http://dx.doi.org/10.5755/j01.ppaa.14.1.10154
}

\begin{abstract}
The aim of the research paper is to find out if the republic of Georgia is likely to have emerging market. Paper analyzes different aspects of emerging market, included: historical background, political situation (international rankings, the role of the international society), economic conditions (FDI inflows, major economic indicators), legal framework. The paper argues that recent economic and political reform efforts have been successful, however, a key concern is the effective implementation of the legal and policy framework for investment environment, leading to measurable improvements.
\end{abstract}

Keywords: emerging market, developing countries, economic progress.

Raktažodžiai: kylančios rinkos, besivystančios šalys, ekonominè pažanga.

\section{Introduction}

An emerging market was a term coined by the World Bank economist Antoine W. van Agtmael in 1981 in reference to nations undergoing rapid economic growth and industrialization (Economy Watch, 2010). The term is often used with 'emerging and developing economies'. The IMF classifies 150 countries as emerging markets based on the composition of countries' export earnings and other income from abroad (International Monetary fund, 2013).

Emerging and developing economies are often transitional economies, shifting from closed economies to open market economies. Often, the transition involves structural or policy reforms such as currency or capital market changes. The level of foreign investment is also critical for an emerging economy. In most cases, increased foreign investment is a sign the economy has a potential. The injection of foreign currency into the local economy aids long-term investment to its infrastructure.

If we look at Eastern European countries it can be observed that countries such as: Belarus, Georgia, Ukraine, Armenia, Azerbaijan and Moldova are more likely to have emerging markets due to their economic and political development. Economic transition of these countries and their integration into the global economy are, in fact, 
the two sides of the coin. There is no economic transition of these countries to market economy without establishing participation of economic actors from this region in the international markets of good, services, capital and labor.

According to Luka Gorlero (2011) "Georgia is the country with an emerging economy in the heart of the Caucasus, a player of the new Silk Road". 20 years have passed since the Soviet Union collapse and during these years is Georgian market becoming more and more liberal and free for foreign investors, therefore, it can be assumed that discussing the economy of Georgia and evaluation of its emerging market will be noteworthy and appropriate for the essay task.

This paper focuses on Georgia as an example of an emerging market. Before entering the market it is quite noteworthy to look at the following indicators and characteristics: historical background, political situation (international rankings, the role of the international society), economic conditions (FDI inflows, major economic indicators), legal framework, etc.

\section{Georgian Market Development}

Post communist transformation which has been an ongoing process for the last twenty years in Eastern Europe, seemed to be quite complicated for the republic of Georgia. Mentioned complications had objective and subjective motives. Firstly, parallel to economic reforms the process of creating independent republic was a major issue, proceeding with a civil war and other types of armed struggles. Therefore, only after improvement of criminal conditions, was it possible to impose suitable legislations and even more, to enforce them.

After the fall of the Soviet Union, main concern for the republic of Georgia was its economic transformation from social to capitalist system of economy. Naturally, these processes demanded huge amount of time and implementation of right reforms. Consequently, important institutions for market regulations, such as: taxation system, national currency, antimonopoly legislation an etc. were set up.

It should be mentioned, that during the first years of reforms mistakes may have taken place, as for 70 years Georgian government was not entitled to resolve any political and economic issues on its own. However, it can be assumed that, regardless of serious shortcomings, some weak prerequisites for the establishment of free market economy was still created.

One example of this fact was the reform of the land market, which was launched in 1992. During the implementation process the main emphasis was made to meet requirements of all groups of populations, while the reform ignored the main principle of land use - thus resulting in land fragmentation into very small parcels. The issue of separation of public and private sectors was not considered, as well as the need of developing the land market and other important factors, which led to creation of a number of problems in agricultural sector of Georgia (EPRC, 2013).

In 2003, right after the „Rose Revolution” in November, new cascade of reforms started in Georgia. The new government implemented the policy, which meant to 
abolish many regulatory mechanisms of market, in most cases. For instance, in 2005 the government abolished the legislation on antimonopoly activities, the law on free trade and competition was imposed instead. Major changes were carried out in the sectors of labor and tax legislation.

Therefore, for several years there have been debates regarding the efficiency of new reforms. However, there have been some radical changes which had unequivocal positive effects. For example, Sikharulidze (2012) claims that the new tax code, passed in 2005, reduced tax rates and types of taxes imposed on businesses and individuals. The customs code, passed in 2006, reduced the impediments to trade by decreasing the number of customs categories and overall tariff levels for exports and imports. Similar liberalization has taken place in the areas of licensing and permits and labor regulations. Consequently, this transformed Georgia into one of the most liberal countries in the world when it came to institutional framework. In addition to this, mentioned changes helped Georgia to integrate into the globalization process.

\section{International Rankings}

Against the background of growing processes of globalization, international capital investment plays a crucial role Georgia's economic development, as an emerging market. Global trends affected Georgia in at least two ways. First, new capital became available in international markets, with developing countries trying to attract it to their domestic markets. Second, government of Georgia tried to attract it to their domestic markets that characterized by reforming its local market. Reforms included reducing transactional costs, which is considered to have a fundamental role in market selection.

In terms of reducing transactional costs over the last few years, Georgia has recorded a remarkable improvement in the World Bank's "Ease of Doing Business" indicator. Breaking into the Doing Business (DB) report's world top 20, and receiving the World Bank's award for top-reformer in the years 2006 and 2008.

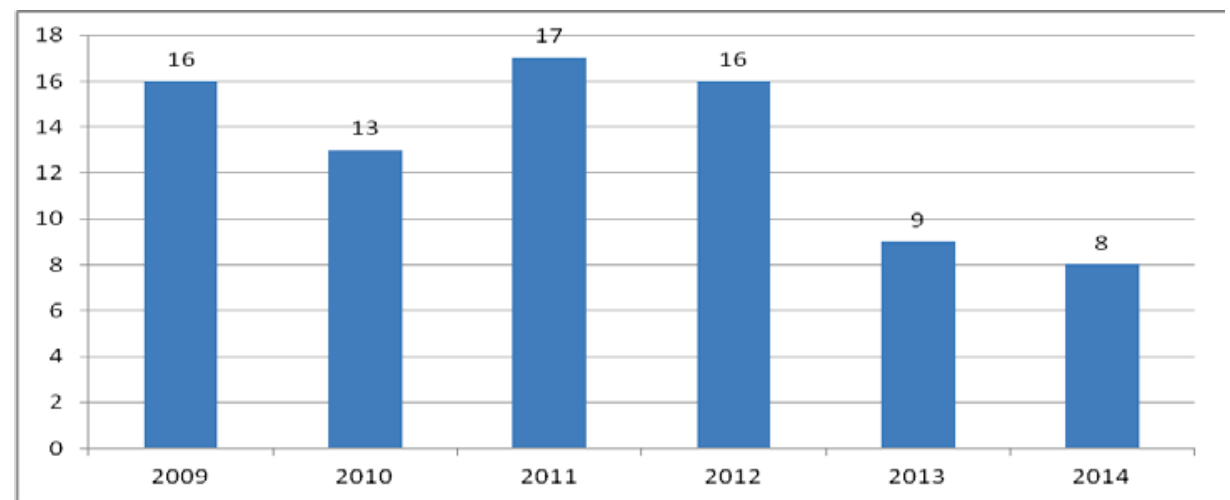

Figure 1. Georgia's position according to the „Ease of Doing Business” 2009-2014 Years, www.doingbusiness.org (2013) 
According to Figure 1, Georgia's positions reached their maximum in 2014 among 189 countries, compared to last 5 years. The World Bank's Doing Business indicator covers the evaluation of different factors, such as: Starting a business, dealing with construction permits, getting electricity, registering property, getting credit, protecting investors, paying taxes, trading across borders, enforcing contracts and resolving insolvency. It can be assumed that, index comprises several indicators that provide first insights into Georgia's institutional framework characteristics; It also reveals that the country's main goal is to ease the rules for companies and reduce the time devoted to complying with regulations (EPRC,2013). In addition to this, a considerable portion of this goal has already been achieved as starting a business and dealing with permits and registration currently requires only a few days.

However, besides the mentioned indicators, the World Bank's Doing Business includes only small set of the factors and considerable number of crucial components such as: a country's macroeconomic stability, the quality of infrastructure, the level of corruption is out of scope of the evaluation.

The World Economic Forum's Global Competitiveness Report, ranks countries according to the competitiveness of their economies, and provides a comprehensive picture of the investment climate and its determinants. Report covers weighted average of many different components, each measuring a different aspect of competitiveness. These components are grouped into 12 pillars of competitiveness: Institutions, Infrastructure, Macroeconomic Environment, Health and Primary Education, Higher Education and Training, Goods Market Efficiency, Labor Market Efficiency, Financial Market Development, Technological Readiness, Market Size, Business Sophistication and Innovation (www.weforum.org, 2013).

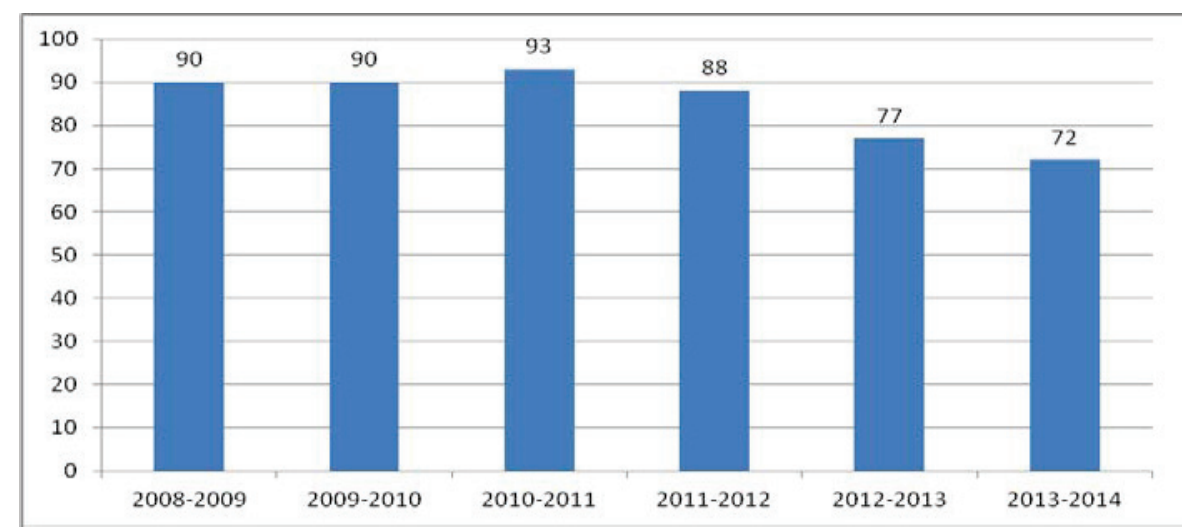

Figure 2. Georgia's position according to the Global Competitiveness report, http://www.weforum.org/ (2013)

According to Figure 2, in general, Georgia improved its ranking by 5 points with an overall score of 4.15 and ranked 72 nd among 148 countries. According to the 
report, there are several pillars in which Georgia has less effective policy. For instance, venture capital availability has 2.29 out of 7 seven points, thus placing a country on $106^{\text {th }}$ position among 148 countries, which is a quite law indicator. In addition to this, pillars such as: High education and training, financial market development and Business sophistication and Innovation stays below the world average rate.

A well-developed infrastructure plays a crucial role in economic progress. Easy and smooth circulation of goods and employees that is guaranteed by adequate infrastructure ensures that the market can function effectively. Moreover, the quality of roads, the supply of electricity and other infrastructural components constitute the starting base for establishing attractive investment climate.

Infrastructure was an obstacle to development for Georgia in the past, and the funds required to make improvements were missing for a long time. However, in the last few years the Georgian government's efforts to provide a reliable infrastructure have been successful, which has been reflected in a stable rise in nearly all the indicators which is included in the pillar of infrastructure.

According to the Global Competitive Index, being at the efficiency-driven stage of development ${ }^{3}$ is not enough to increase investment potential, moreover, the report shows that nowadays Georgian emerging market is less effective to help investors expend their money in Georgia. However, it can be assumed that the government of Georgia $(\mathrm{GoG})$ is focused on the reforms which will bring long-term social welfare.

\section{The Role of International Societies}

In addition to the international rankings, a significant task of economic strategy of Georgia is comprehensive collaboration with the rest of the world, in order to strengthen relationships with international organizations, to achieve successes on the way to labor distribution and settling placement within world market. The objective of the economic strategy is to accelerate economic ties with other friendly states. One example of such kind of collaboration is the Charter between Georgia and United States of America. Mentioned document, affirms the importance of The United States of America and Georgia's relationship as partners and strategic allies. The Charter intends to deepen partnership to the benefit of both nations and expand cooperation across a broad spectrum of mutual priorities (USA, Department of state, 2009).

The Charter consists of preamble and V sections. According to the section III: „The United States and Georgia intend to expand cooperation to enhance job creation and economic growth, support economic/market reform and liberalization, continue to improve the business climate, and improve market access for goods and services. Recognize that trade is essential to promoting global economic growth, development, freedom, and prosperity. The United States endeavors to facilitate the integration of

${ }^{3}$ WEF classifies the development of each country's economy into one of the following stages: stage 1-Factor Driven, Transition from stage 1 to 2, stage 2- Efficiency driven, Transition from stage 2 to stage 3, stage 3 - Innovation Driven. 
Georgia into the global economy and appropriate international economic organizations" (USA, Department of state, 2009), it would be noteworthy to mention, besides these activities, the U.S. is the country which is had huge impact Georgian market economy development.

In addition to this, for the last several years GoG has been trying vigorously to deepen integration processes between Georgia and the European Union (EU). Nowadays, there are lack of investment resources in Georgia, in addition to this, the unemployment rate stands as high as $15 \%$, on the other hand, the share of population under poverty threshold is approximately $9 \%$ (www.geostat.ge 2013), therefore, it is very important for Georgia to find its place in the EU market, in order to boost investments and rise export potential. It has to be mentioned that one of the main trade partners and traditional markets for Georgia is Russia, which had been closed for Georgian products because of embargo.

Consequently, signing deep and comprehensive free trade agreement (DCFTA) with the EU is crucial for Georgia's economic development. However, Georgia already enjoys Generalis System of Preferences (GSP+), which spreads over 7200 Georgian products and envisages release of the exported goods and unilateral tariff reduction. (GSP+) format has two main features: It provides growth of the exports of the beneficiary state and helps its integration into EU. However, it can be firmly announced that GSP+ format is less encouraging for diversifying Georgian export products. Under this scheme, Georgia by far has been exporting only traditional products to the EU. Therefore, it is clear that for deepening the trade relations between Georgia and the EU, not only the activities for lifting the trade barriers are necessary, but rather it is important to help Georgia in creation of an attractive investment climate.

The latter is the aim of signing DCFTA, i.e., to create attractive investment environment. Principle difference between a Simple Free Trade Agreement (Simple FTA) and DCFTA is that, according to Kakulia M. at el. (2008) FTA implies only complete liberalization of tariffs while DCFTA-format along with lifting of tariff barriers stipulates implementation of radical reforms including the spheres of competition policy and investment promotion, resulting in a necessity of boosting investment attractiveness of Georgia and reducing risk premium connected with investments.

There have been many controversies regarding the outcomes of DCFTA. However, a Polish organization CASE commissioned by the European Commission completed a research on opportunities after signing the free trade agreement between Georgia and the EU. According to the Case research (2008), Georgia will get a positive effect as a result of signing of DCFTA.

According to the study results, within the next 5 years a significant impact will be made on the volume of foreign direct investment inflow, dynamics of rates, salaries and service balances. For example: following DCFT activation, GDP of Georgia will be increased additionally by $6,5 \%$ within the next 5 years, which means an additional 1,3\% annual GDP growth on average (Case research 2008). 


\section{Institutional Framework}

In general, the legislative framework provides the grounds on which economic agents interact, and sets legal boundaries based on formal and informal regulations and conventions for socioeconomic activity. Its objective is to support an increase in the competitiveness of local companies and increase FDIs.

As previously noted, Georgia has been following a distinctly liberal approach so far, which has restricted government interference in the market, keeping it to a minimum. This approach has significantly influenced the current reforms and the refinement of the institutional framework. The importance of the free market and less regulation for the Georgian government is reflected in many international rankings which have already been discussed above.

Regulator of investment activities in Georgia is the law on, Promotion and Guarantees of Investment activities. The main target of the law is to "determine legislative policies of investment development. Consistent to the law, investment is an estate or intellectual value or right, which will be used to have profit in the territory of Georgia", (Parliament of Georgia, 1996). However, according to the Global Competitiveness Report (year?) Georgia's ranking in intellectual property protection is relatively low.

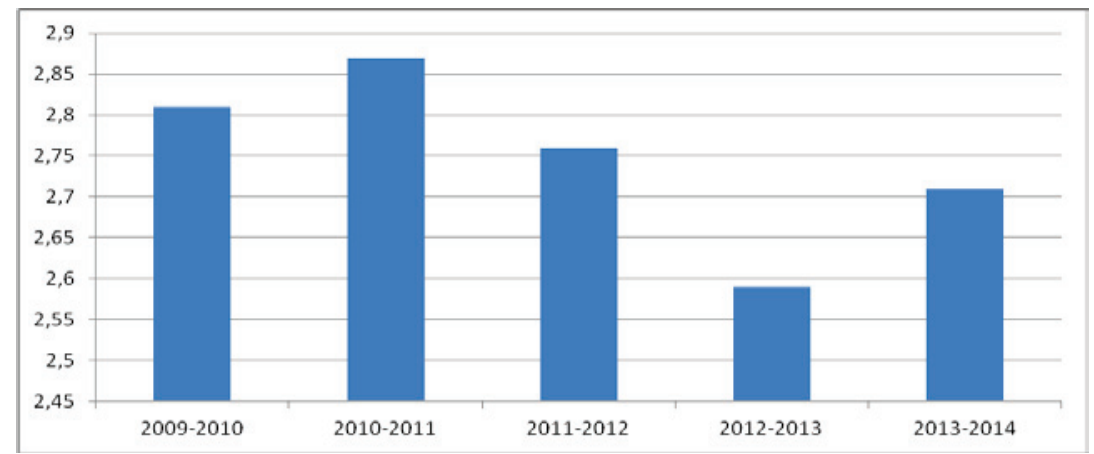

Figure 3. Intellectual Property Protection 2009-2013. http://www.weforum.org/ (2013)

Figure 3 shows the general trend of intellectual property protection according to the Global Competitiveness report. At the first glance, it can be concluded that from 2009 to 2013 rank of intellectually property right is low. For example in 2013-2014 Georgia's position in this sphere is $124^{\text {th }}$ among 148 countries, on the other hand according to the World Bank's "Ease of Doing Business" indicator the country is $8^{\text {th }}$ among 189 countries.

In briefly it can be said that transaction costs on Georgian market are quite low. However there is a lack of institutional development which will provide a healthy competition and protection for foreign investors. During the recent years, GoG has made emphasis on institutional changes though from the practical implementation point of view. However, the international societies require more activities from the Georgian side. 


\section{FDI Flowing in Georgia}

In general, foreign investors face many barriers when investing in emerging markets. It can be distinguished into two groups of direct barriers to investment and another group of indirect barriers. In the first group are direct restrictions on foreign ownership. In the second group are exchange and capital control that affects investment in emerging markets, in addition to this lack of legislative framework development can be listed in the second group.

As growth of the Georgian economy is mainly based on foreign financial sources, GoG maximally tried to avoided problems which were connected to direct restrictions on foreign investments. However, problems such as: Institutional environment, insufficient educational background and lack of legislative norms. In general according to the according to the World Bank research (2009), the main factors which have negative indirect effects on investments are: political uncertainty (28\%), unstable macroeconomic environment (23\%), taxation (19\%), legislative regulation (10\%), corruption $(10 \%)$.

For Georgian emerging market especially FDI plays a crucial role in the country's development, because FDI are mainly focused on long term infrastructural projects, which is impossible to be financed just by the local banking sector.

FDI has given a sizeable impetus to rapid economic growth of Georgia, notably since early 2000s onwards. In light of the recent decline in the absolute volume of inward investment, the GoG is facing a serious challenge of attracting FDI at level necessary for maintaining the pace of growth recorded earlier, when FDI inflows were considerably higher. Due to unfavorable political and economic developments, largely global in their nature, such as the brief but impactful war with Russia and protracted global financial crisis, Georgia is still struggling to reach the pre-crisis FDI inflow-volume of more than 2 billion USD in 2007.

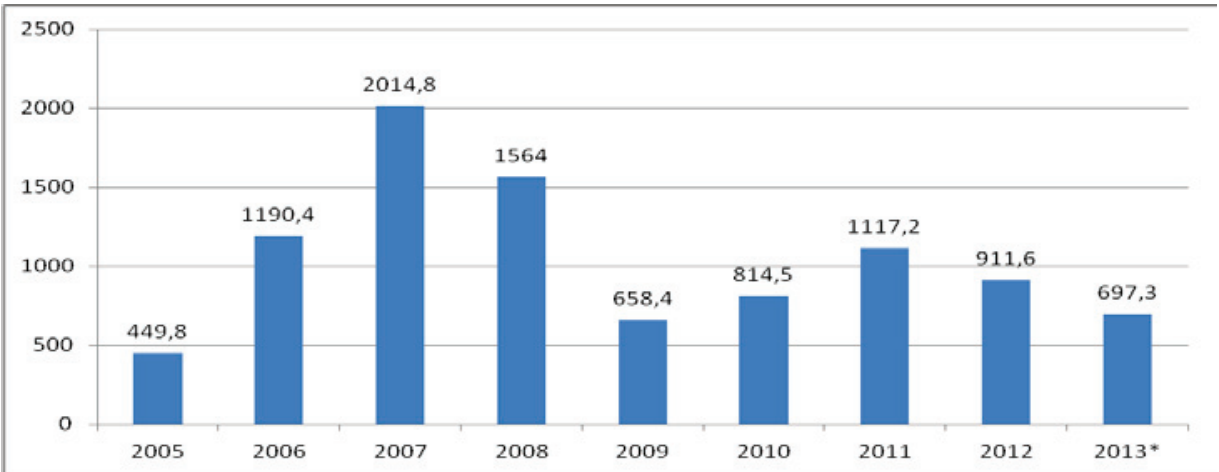

Figure 4. Foreign Direct Investment to Georgia.2005-2013 (mil.USD) www.geostat.ge (2013) 
According to Figure 4, FDI reached its peak in 2007 with 2014.8 million USD, However after that year it had been dropping gradually and slumped in 2009 with 658.4 million USD. The main reason for such a low level of FDI in 2009 was the Global financial crisis and the Russian-Georgian war in 2008. Prior to the armed conflict of August 2008, the Georgian economy had displayed robust growth, partly due to the success of the reform process but the conflict led to a fall in investment and a serious decline in economic growth with increasing unemployment and decreasing Georgian budget in this year by 1 billion GEL ${ }^{4}$ (www.geostat.ge 2013). In addition to this, political instability in Georgia added substantial risk premiums to returns and deter some foreign investors.

\section{Conclusions}

1. The failure to develop deep and efficient capital markets may have important consequenceson Georgia market. Growing empirical evidence suggests that investment development is not just correlated with a healthy economy, but it actually causes economic growth and has positive impact on poverty alleviation and income distribution as well (Torre, A. et al. 2006). Therefore, better understanding of the drivers of capital market development and the reasons for the perceived failure of reform effort in many emerging economies can provide useful guidance to policy makers.

2. Despite the fact that Georgian market appears particularly poor, GoG still had many efforts already undertaken to improve the macroeconomic environment and reform the institution in order to foster investment and legislative framework development. Consequently, it can be assumed that Georgia has potential to increase its investment development, as it has all major frameworks, which contribute to attract foreign investors to invest in Georgian emerging market.

3. Georgia is facing severe economic problems that determine key challenges for poverty reduction, sustainable economic development and creation of attractive investment climate. While recent economic and political reform efforts have been successful, a key concern is the effective implementation of the legal and policy framework for investment environment, leading to measurable improvements. Shortterm economic growth must be balanced with a long-term sustainable development; otherwise, unsustainable development will complicate long-term economic development.

\section{Reference}

1. Arias, J., Artuc, E., Lederman, D., Rojas, D. (2013). "Trade Policy, Labor Adjustment and Development"p.16 [Internet], Available from: from:http://wwwwds.worldbank.org/external/default/WDSContentServer/IW3P/IB/2013/ 09/20/000158349_20130920085912/Rendered/PDF/WPS6614.pdf [Accessed 01 September 2013].

\footnotetext{
${ }^{4}$ Georgian Lari
} 
2. Bekaert, G., (1995) "Market Integration and Investment Barriers in Emerging Equity Markets" The World Bank Economic Review, Vol. 9, [Internet] Available at: http://www-

wds.worldbank.org/external/default/WDSContentServer/WDSP/IB/1999/09/25/00017883 0_98101911432652/Rendered/PDF/multi_page.pdf.

3. Dyker, D., Emerson, M., Gasiorek, M., Holmes, P., Jakubiak M., Jungmittag, A., Korchagin, V., Maliszewska, M., Pertaia, G., Polyakov, E., Roundio, A., Tokmazishvili, M., (2008) "Economic Feasibility, General Economic Impact and Implications of a Free Trade Agreement between the European Union and Georgia" Center for Economic and Social Research, Warsaw, Poland.

4. Economic Policy Research Center. (2013) “Georgian Diaspora Study, 17 [Internet] Available from: http://eprc.ge/admin/editor/uploads/files/GIZ_Georgian_Diaspora_Study_A4_Book_Prin t.pdf [Accessed May 2013].

5. Economy Watch Community (2013) "Emerging Markets", Available at: http://www.economywatch.com/world_economy/emerging-markets [Accessed June 2009].

6. Georgia. Parliament of Georgia. (2013 Law about "Promotion and Guarantees of Investment activities". Tbilisi. Available at: http://parliament.ge/index.php?option $=$ com_content\&view=article\&id=2\&Itemid=34\&la ng=ge [Accessed 12 November 1996.

7. Gogolashvili, K., Akobia, E., Kapanadze, S., Bregvadze, R.,Beruchashvili T., Kakulia, M., Chokheli. N., Chkoidze, V. Maniokas, M., (2009) 'European Union and Georgia: Current issues and prospects fo the future', Georgian Foundation for Strategic and International Studies (GFSIS).

8. Gorlero, L., (2013) "Emerging Markets Investment News" Emerging Markets Investment News blog, 15 September. Available at: http://emerging-markets-investmentnews.blogspot.com/ [Accessed January 2007].

9. Guillermo, A.C., Izquierdo, A., Talvi, E., (2006) "Phoenix Miracles In Emerging Markets: Recovering Without Credit From Systemic Financial Crises" NBER Working Paper Series. [Interenet] Available at: http://www.nber.org/papers/w12101.pdf?new_window=1.

10. International Monetary Fund (2013). Available at: http://www.imf.org/external/index.htm.

11. Mrak, M., (2000) "Globalization: Trends, Challenges and Opportunities for Countries in Transition" United Nations Industrial Development Organization, [Internet] Available at: http://www.unido.org/fileadmin/import/userfiles/puffk/mrak.pdf.

12. National Statistics Office of Georgia (2013). National Statistics Office of Georgia available at: www.geostat.ge [Accessed December 2005].

13. The World Bank (2013), "Doing Business Project". Available at:http://www.doingbusiness.org/ [Accessed 2002].

14. The World Economic Forum (2013). Available at: http://www.weforum.org/.

15. Torre, A., Schmukler, L. S. (2006) "Emerging Capital Markets and Globalization the Latin American Experience" Copublication of Stanford Economics and Finance, and 
Imprint of Stanford University Press and Finance. Available at: http://siteresources.worldbank.org/DEC/Resources/Schmukler_ECMGBookwithdelaTorr e.pdf.

16. Sikharulidze, D. (2012). "Motivations for Direct Investment and Their Impact on Georgia's Economy", Economics and Business, p.61 (6), [Internet]. Available from: http://tsu.edu.ge/data/file_db/economist_faculty/ekonomika\%206-2012.pdf [Accessed 21 January 2008].

17. USA. U.S. Department of State. (2013) "United States-Georgia Charter on Strategic Partnership"

Washington, Available at: http://www.state.gov/p/eur/ci/gg/usgeorgiacommission/ [Accessed 9 January 2009].

Nino Paresashvili

\section{Reformos ir politika, skatinančios augančią rinką Gruzijoje}

\section{Anotacija}

Straipsnio tikslas yra atskleisti, kiek Gruzijos Respublika yra pasirengusi plètoti rinką. Darbe aptariami ịvairūs augančios rinkos aspektai: istorinis palikimas, politinė situacija, vykdomų reformų eiga. Analizuojami tarptautiniai reitingai, aptariamas pačios tarptautinès bendruomenès vaidmuo, skatinant ekonominių santykių plètrą Gruzijoje. Ypatinga vieta skiriama rinkos ekonominių sąlygų (pagrindiniai ekonominiai rodikliai) ir teisinès sistemos analizei. Straipsnyje diskutuojama, kad nors pastarosios ekonominès ir politinès reformos Gruzijoje buvo sėkmingos, pagrindinė problema - kaip suformuoti efektyvią, investicijoms palankią teisinę ir politinę aplinką.

Nino Paresashvili, Doctor of Social Sciences, is Associate Professor at the Faculty of Economics and Business, Ivane Javakhishvili Tbilisi State University.

E-mail: ninoparesashvili@gmail.com

Nino Paresashvili - Tbilisio valstybinio Ivane Javakhishvili universiteto, Vadybos ir administravimo katedros, docentè, socialinių mokslų daktarè.

E. paštas: ninoparesashvili@gmail.com

Straipsnis įteiktas redakcijai 2015 m. sausio mèn.; recenzuotas; parengtas spaudai 2015 m. vasario mèn. 